\$ 3rd volume 1986 contains in excess of 8500 names

\$ Three parts: main bibliography; design area index: country index

\$ Published and unpublished sources with emphasis on material not otherwise indexed
\$ Information cumulates in each volume

\$ 23 design areas now included

\$ Indexing both current \& retrospective to 1850

申 International coverage; foreign and English language sources

3rd year and still $£ 199$

\title{
FASHION UPDATE
}

\section{Fashion shows from Paris, London, New York \& Milan}

Over 60 design houses and over 1300 photographs in colour each year

\$ Arranged by country and designer for easy access

中 Irreplaceable archival asse
\$ Colour microfiche supplied in holders and ring binder \$ Valuable resource for fashion and design history students 中 Photography by Niall McInerney

\section{NEW TITLES}

\$ LOCAL \& TRADITIONAL COSTUMES WORLDWIDE More than' 4000 illustrations of local costume from all over the world, arranged by continent and country using collections in Prints \& Drawings and the Naticnal Art Library at the V\& A Printed catalogue included

† RUSSIAN BALLET of Sergei Diaghilev

An exciting and colourful personal insight into the world of ballet and theatre between the wars. 98 page, 1000 name printed index

HEAL'S CATALOGUES - 1850-1950

This well known furniture store issued regular catalogues from 1850 . These are reproduced on $B / W$ microfiche, giving an invaluable resource for history of design and social history
申 TEXTILE DESIGNS - 1850-1985 in the V \& A Over 2500 designs including famous designers from William Morris to Tricia Guild. Includes fully indexed printed Summary Catalogue

申 STAFFORDSHIRE CERAMICS in the Stoke on Trent Museum

The comprehensive collection covers all periods and styles of pottery from the earliest pre-historic pots to recent examples from famous studios. Fully indexed printed catalogue

\$ NETSUKE in the $\mathbf{V} \& \mathrm{~A}$

There are 524 examples of these interesting and beautiful miniature carvings from Japan, together with a printed catalogue and index

\section{The Conway Library}

COURTAULD INSTITUTE OF ART

Photographic Research Library for Art History on Microfiche

800,000 photographs in collection

Available as complete set or parts

\section{ARCHITECTURE A}

France \& Italy to 20 th century

2. ARCHITECTURE B

Britain, Germany, Spain and the rest of

Europe, South America, Africa, Islamic areas

etc. to 20 th century

\section{ARCHITECTURE C}

Architectural drawings 14 th to 20 th century

\section{SCULPTURE}

15 th to 20 th century

5. MEDIEVAL ARTS

Sculpture, Metalwork, Ivories, Wall \& Panel

Paintings etc. Greek to 14 th century:

Byzantine Monuments with integral

decoration

6. MANUSCRIPTS

Western, Byzantine and East Christian

\section{SEND FOR LEAFLET \& DETAILS OF PRICE \\ EMMETT PUBLISHING}

PO BOX 35, Haslemere, Surrey GU27 1 HZ 'phone (0428) 54443 
Victorian Fashion

Art Deco Fashion

Austerity Fashion

Fashion and Glamour (1930's)

Theatre and Cinema Design (1930's)

French interior Design (1930's)

Garden Design

Victorian Churches

West Riding Country Houses

Architecture of Newcastle Upon Tyne

Architecture of Leeds

Architecture of Manchester

Shop Fronts

Small Towns, U.S.A.

Working Class Terraced Housing

Modern Urban Housing Developments

English Painting (1917-1921)

The Ashington Group

Animation

Street Murals

Fairground Art

Blackpool lluminations

British Tattoos

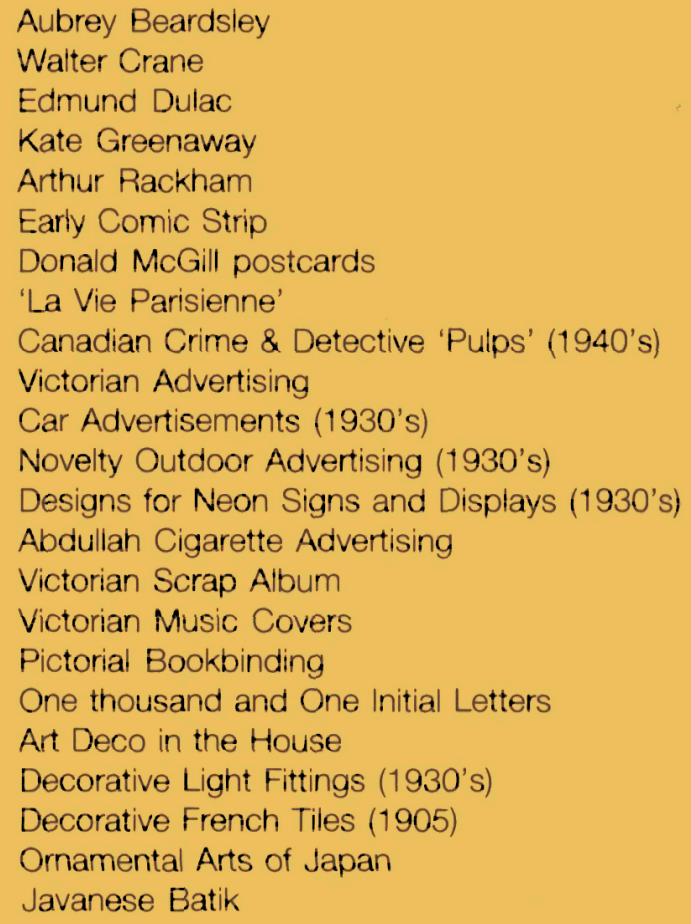

These are just some of the titles from our latest catalogue which covers Illustration, Advertising, Publicity, Painting, Sculpture, Architecture, Interior Design, Garden Design, Photography, Fashion, Graphic Design and Industrial Design among many others. If you are interested, please send for your free copy now.

\section{by}

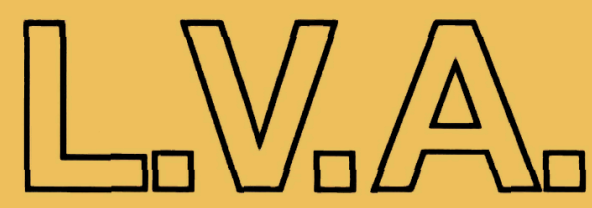

\section{LAMBTON VISUAL AIDS}

9, Side, Newcastle upon Tyne NE1 3JE. Tel: 091-232-2000. 